\title{
Mapping Solar Pond by GIS and Analytic Hierarchy Process
}

\author{
Mohamed Nower, Mohamed Embaby, Ashraf Elashaal, El-serafy S
}

\begin{abstract}
In terms of the importance of solar radiation sustainability in Egypt, this research was initiated with the objective of mapping solar ponds to provide solar energy by Geographic Information Systems (GIS) and multi-criteria decision-making method to ensure their efficiency, in terms of cost. Primarily, literature in the field of solar ponds and clean energy was assembled, reviewed, analyzed and categorized to deduce data about solar pond locations and analyze such data. Accordingly, different variables were considered such as power line stations, road networks and cities). In addition, land cover as environmental parameter was considered. Furthermore, technical variables like direct normal radiation, temperature, wind and relative humidity were taken into account. ArcGIS process was applied and solar pond technique locations were selected. The deduced data were comprehended, analyzed, and presented to perceive a complete data picture about Egypt, from which it was apparent that different zones have different characteristics, in terms of the capability of encompassing solar ponds. Based on the investigation results, it was concluded that Al Wadi Al Jadid Governorate and some spatial areas show in mapping satisfies the renewable energy potential. In addition, it was recommended to implement solar ponds in their vicinity, as they satisfy the solar pond requirements, in terms of efficiency and cost.
\end{abstract}

Keywords: Solar Pond, Solar Energy, Geographic Information Systems

\section{INTRODUCTION}

In 1900, 10 million barrels of oil was consumed worldwide. It is expected to increase to 400 million barrels by 2030. This means that in the future, more energy will be consumed worldwide. Consequently, more pollution is anticipated to discharge into the atmosphere. Accordingly, the world decided to go for clean energy. Solar energy is a clean energy with no emissions during generation. This energy implements advanced technology to transform it to electrical energy by photovoltaic panels, solar pond or direct heating. Solar pond is a recent technique that emerged worldwide to provide clean energy. Accordingly, this

Revised Manuscript Received on March 17, 2020.

* Correspondence Author

Mohamed Nower*, Associate Researcher, National water research center, Cairo, Egypt. Email: nower2020@gmail.com

Mohamed Embaby, Researcher, National water research center, Cairo, Egypt. Email: m_moh1979@yahoo.com

Ashraf Elashaal, professor Emeritus, National water research center, Cairo, Egypt. Email: aaselashaal@yahoo.com

El-serafy S, Professor and head of the hydraulics and engineering department of Ain Shams University, Cairo, Egypt. Email: sonia_elserafy@eng.asu.edu.eg

(c) The Authors. Published by Blue Eyes Intelligence Engineering and Sciences Publication (BEIESP). This is an open access article under the CC BY-NC-ND license (http://creativecommons.org/licenses/by-nc-nd/4.0/) investigation was commenced with the impartial of mapping solar ponds by GIS and multi-criteria decision-making method to ensure their efficiency, in terms of cost. Literature in the field of solar ponds were accumulated and revised. Data sets regarding ponds were reviewed and processed. The data sets encompassed solar direct normal radiation, temperature, wind speed and relative humidity. Based on the assembled literature, some investigators stated that the world faces an enormous problem in energy. Others advocated that surplus emissions lead to international agreements to mitigate pollution risks of toxic gases. In addition, the literature documented that Egypt, as a Sunbelt country, unquestionably ratified the Kyoto Protocol on 2009. From the literature, it was clear that many researchers investigated solar ponds. Among them, for example, are the following.

- [1] documented that Egypt became a member to the United Nations Framework Convention on Climate Change.

- [2] advocated that Egypt terrain varies between its lowest level at Qattara Depression (-133 m) and its highest level at Mount Catherine (2,642 m).

- [4] provided the solar direct normal radiation map of Egypt, as it is on the sunbelt, figure (1).

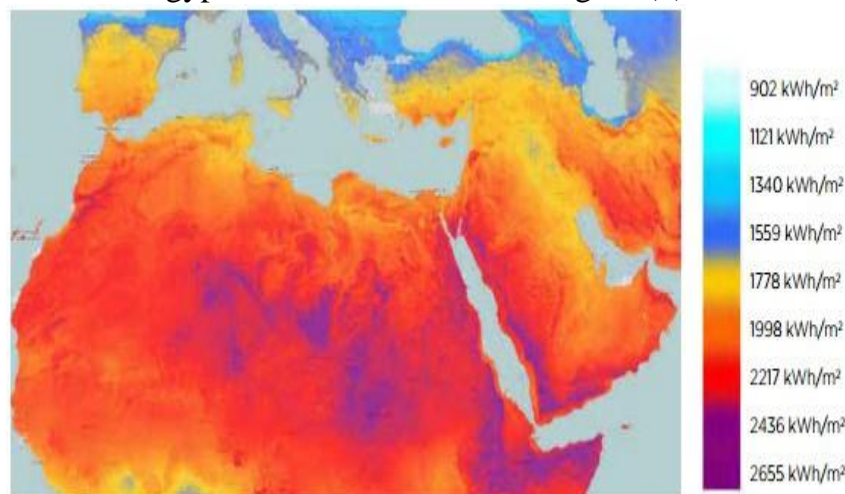

Fig. 1. Solar direct normal radiation map of Egypt and North Africa [4]

\section{DATA ASSEMBLY}

Data was obtained from the literature. These data are presented here, as follows:

- Solar atlas maps for Egypt [4]

- Climatological radiation data from NASA [5]

\section{DATA PROCESSING}

The assembled data were processed, as follows:

Published By:

Blue Eyes Intelligence Engineering

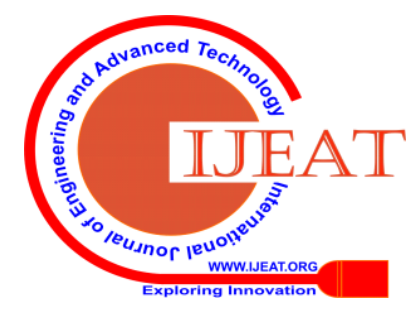




\section{A. Raster Dataset}

During this processing stage, the following was accomplished:

- A solar radiation map was obtained by ArcGIS 10.6.1, A view-shed analysis was executed and table of irradiance, in each sky direction, was obtained.

- A geometric solar radiation model (Solar Analyst) was implemented to calculate insolation maps from digital elevation models (DEM) by ArcGIS (10.6.1).

- The direct normal radiation (KW-hr/m²/day) was obtained, for each month.

- Based on thirty years recorded data form NASA, spatial analysis was achieved.

- Land cover map for half by half degree was obtained from NASA for Egypt, Fig. 2).

\section{B. Vector Dataset}

During this processing stage, the following was achieved:

- ArcGIS converted a solar radiation map from raster dataset to vector dataset at its original resolution and without generalization.

- Graphic output was obtained. It is aesthetically pleasing rather than traditional cartographic representation. It is allowing efficient encoding of solar radiation.

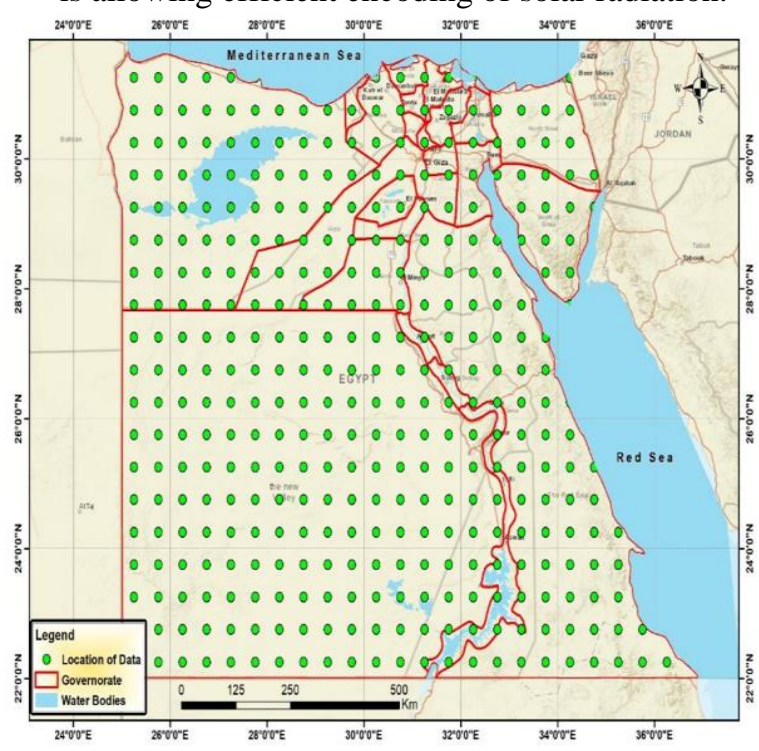

Fig. 2. Data locations in Egypt

\section{APPLYING GEOGRAPHIC INFORMATION SYSTEM}

In order to map solar ponds, geographic information system, and its analysis tools were implemented to prepare map layers with their criteria and weightings of their sub-criteria by:

- Reviewing the previous literature

- Preparing the database of digital maps within GIS software

- Creating suitable buffer zones or special constraints to suit each criterion map

- Transforming Raster maps to Vector maps

- Determining the weightings for the criteria from the final maps

- Determining land suitability index

- Reclassifying the obtained maps

-Applying parameters constraints to map the suitable location for solar ponds

The incorporated technical criteria in the GIS are important, as they determine the potential energy production of the solar ponds. These criteria are as follows:

\section{A. Solar Radiation (Kw-Hr/M $\left./ \mathbf{M}^{2} / \mathrm{Day}\right)$}

Direct Normal Radiation (DNR) was obtained from NASA. It is the amount of solar radiation per unit surface area normal to the straight rays from the sun in grid points shown in Fig. 2) [5]. The ArcGIS software analyzed and modeled specific areas or points in a specific time to model solar radiation. It considered local factors to generate the minimum, maximum, range, mean, standard deviation, coefficient of variation, skewness and kurtosis. These are indicators of the central tendency. Distribution maps of the parameter were produced by ArcGIS (10.6.1) and area of solar energy distributions was obtained for Egypt, Fig. 3) and Fig. 4).

\section{B. Wind Speed $(M / S)$}

Monthly average wind speed at 10 meters above Earth surface for 30-years period (January 1984 to December 2013) was obtained from NASA Egypt [5].

A spatial analyst tool of ArcGIS was implemented to support database wind-speed mapping, analyze and model specific areas or points in a specific time. This tool succeeded to model wind energy. Local factors were input and statistical analysis was carried out to designate the area of wind energy distribution in Egypt, Fig. 5) and Fig. 6).

\section{Temperature (C)}

Data was obtained from NASA Egypt. They are monthly average temperature at 2 meters above Earth surface, averaged over 30-years period (January 1984 to December 2013) [5]. The software ArcGIS supports database temperature distribution mapping, analyzing, and modeling specific areas or points in a specific time to signpost the area of temperature distribution in Egypt; Fig. 7) and Fig. 8).

\section{Relative Humidity Percentage}

Data was obtained from NASA Egypt. It encompassed the ratio of actual partial pressure of water vapor to the partial pressure at saturation in percent. The monthly average of relative humidity at 2 meters above Earth surface, averaged over 30-years period (January 1984 to December 2013) [5]. ArcGIS was implemented to designate the area of relative humidity percentage distribution in Egypt; Fig. 9) and Fig. 10).

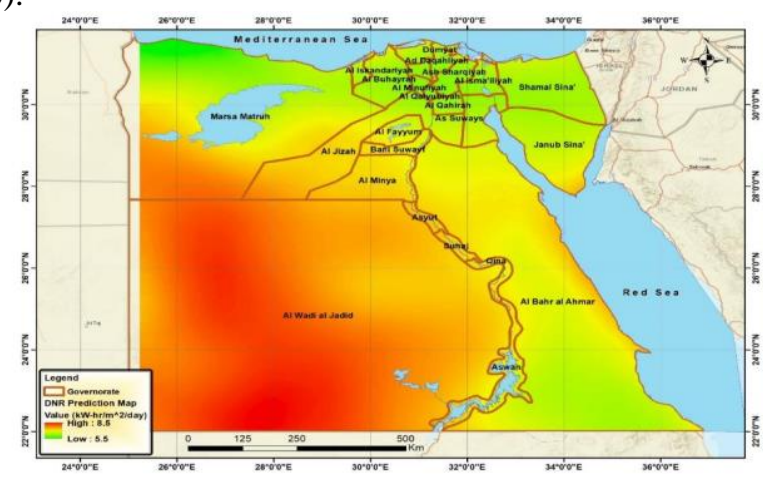

Fig. 3. Direct normal radiation raster in Egypt

Published By:

Blue Eyes Intelligence Engineering

\& Sciences Publication

(C) Copyright: All rights reserved.

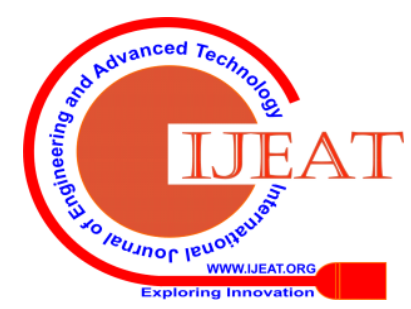




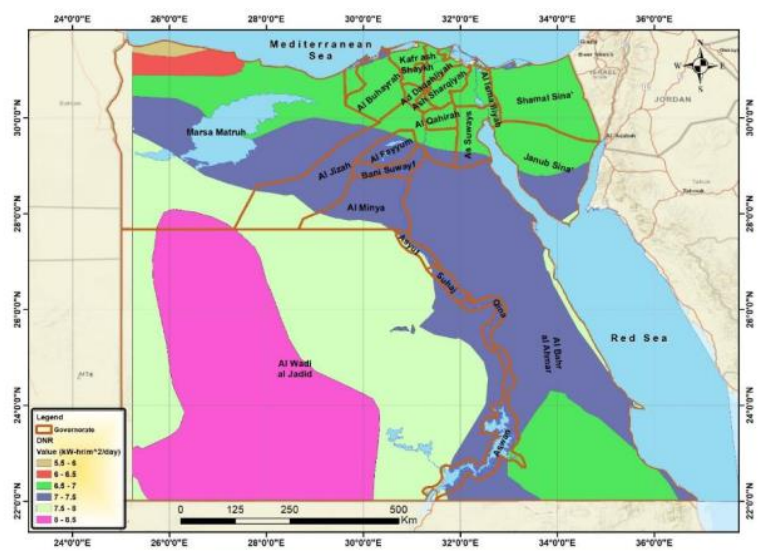

Fig. 4. Direct normal radiation in Egypt

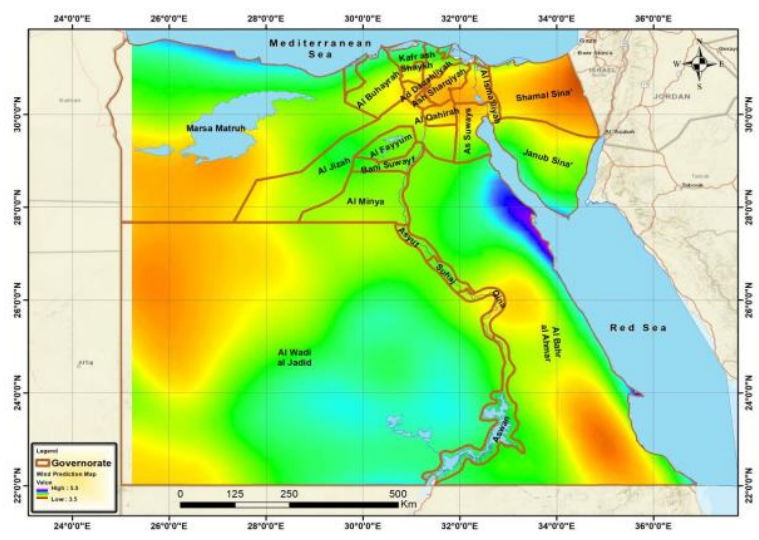

Fig. 5. Wind speed raster in Egypt

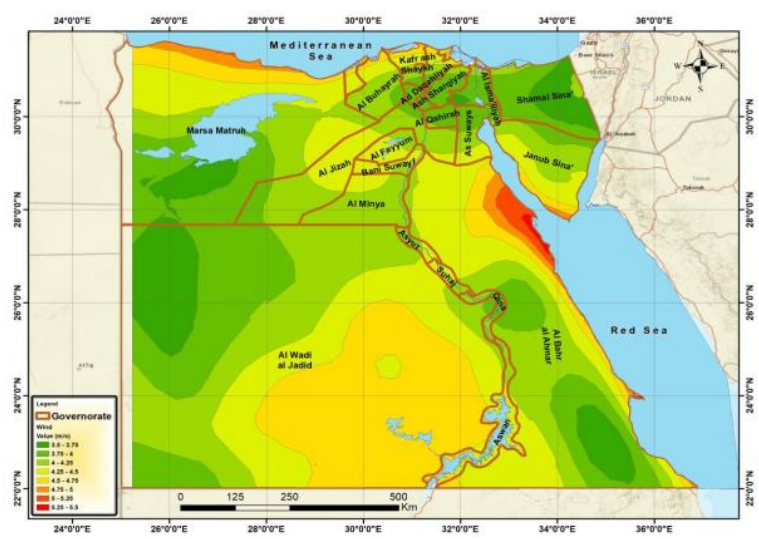

Fig. 6.Wind speed in Egypt

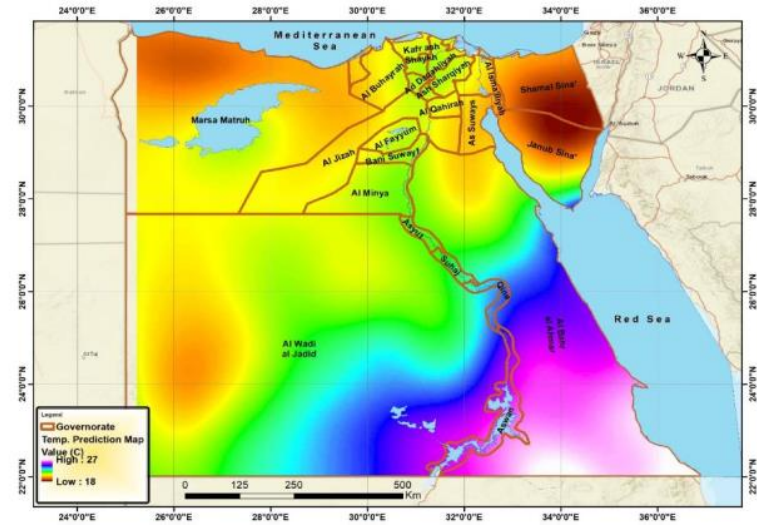

Fig. 7.Temperature distribution raster in Egypt

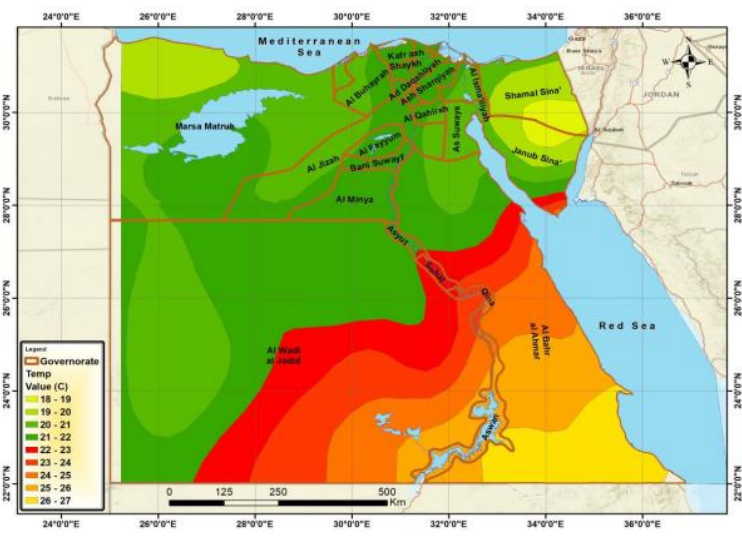

Fig. 8. Temperature distribution in Egypt

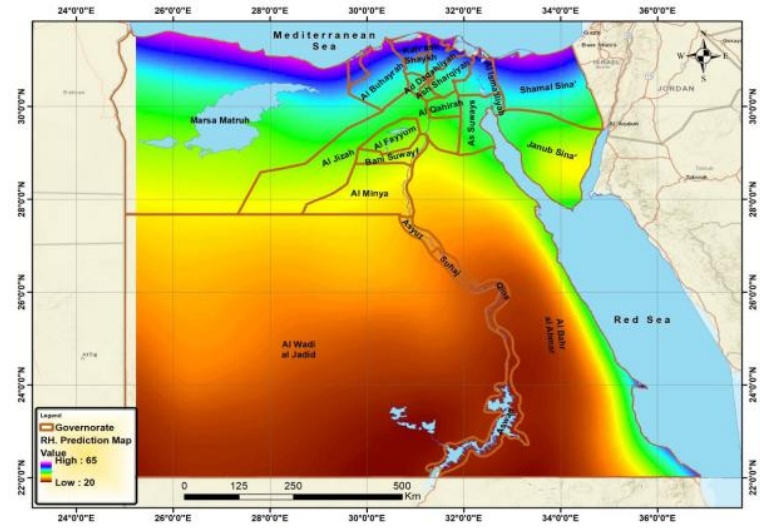

Fig. 9. Relative Humidity raster in Egypt

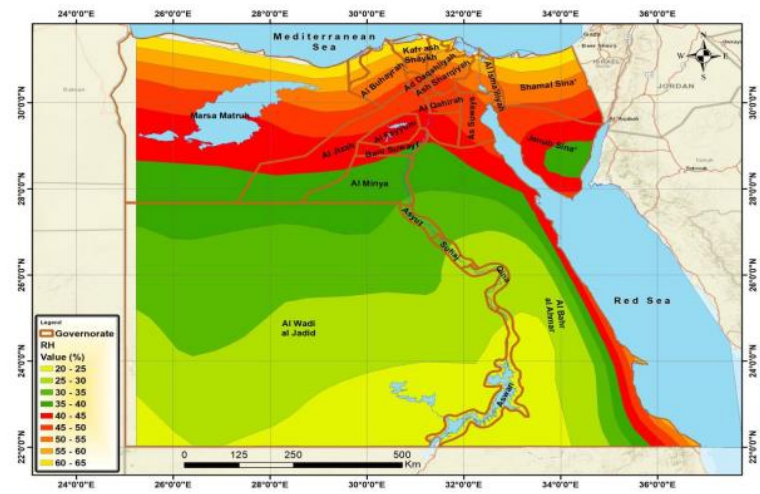

Fig. 10. Relative Humidity in Egypt

Published By:

Blue Eyes Intelligence Engineering DOI: 10.35940/ijeat.D6757.049420

Journal Website: www.ijeat.org

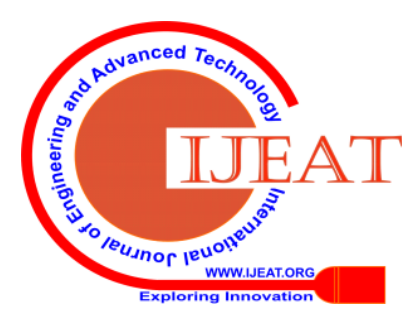




\section{CRITERIA LIMITS AND CONSTRAINS}

Constrains for each criterion were obtained from the

- Table- 1).

- The impact of factors was calculated and compared to Egyptian records of climate conditions, Table- 2). literature, as follows:

- Surveys were carried out for some places executed and successful examples of implemented solar ponds,

- Each element was obtained and reclassified according to the regions of solar ponds worldwide, Table- 2).

Table- 1: Some executed and successful examples of implemented solar ponds

\begin{tabular}{|c|c|c|c|c|c|c|}
\hline Lat. & Long. & Location & $\begin{array}{c}\mathbf{D N R} \\
\left(\mathbf{k W}-\mathbf{h r} / \mathbf{m}^{2} / \mathbf{d a y}\right)\end{array}$ & Temp. (C) & $\begin{array}{c}\text { Wind } \\
(\mathbf{m} / \mathbf{s})\end{array}$ & $\mathbf{R} \mathbf{H}$ \% \\
\hline 31.1976 & 35.3625 & Ein Bokek, Israel & 6.01 & 19.81 & 3.1 & 52.8 \\
\hline 31.8083 & 35.4790 & Beith Ha'rava, Israel & 6.01 & 19.94 & 3.11 & 56.53 \\
\hline 31.7717 & -106.50 & $\begin{array}{c}\text { University of Texas (El } \\
\text { Paso), US }\end{array}$ & 6.55 & 17.15 & 3.86 & 38.06 \\
\hline-17.099 & 145.800 & $\begin{array}{c}\text { Pyramid Salt Ltd, } \\
\text { Australia }\end{array}$ & 5.83 & 22.06 & 2.93 & 81.26 \\
\hline 41.3859 & 16.0857 & $\begin{array}{c}\text { Margherita Di Savoia, } \\
\text { Italy }\end{array}$ & 4.95 & 16.05 & 4.16 & 69.63 \\
\hline
\end{tabular}

Table- 2: Egypt classification with limit factors affecting the choice of solar ponds

\begin{tabular}{|c|c|c|c|c|c|c|c|}
\hline \multicolumn{2}{|c|}{$\begin{array}{c}\text { DNR } \\
\left(\mathbf{k W}-\mathbf{h r} / \mathbf{m}^{2} / \text { day }\right)\end{array}$} & \multicolumn{2}{|c|}{ Temp. (C) } & \multicolumn{2}{|c|}{ Wind $(\mathrm{m} / \mathrm{s})$} & \multicolumn{2}{|c|}{ RH \% } \\
\hline 1 & $5.5-6$ & 1 & $18-19$ & 1 & $3.5-3.75$ & 1 & $20-25$ \\
\hline 2 & $6-6.5$ & 2 & $19-20$ & 2 & $3.75-4$ & 2 & $25-30$ \\
\hline 3 & $6.5-7$ & 3 & $20-21$ & 3 & $4-4.25$ & 3 & $30-35$ \\
\hline 4 & $7-7.5$ & 4 & $21-22$ & 4 & $4.25-4.5$ & 4 & $35-40$ \\
\hline 5 & $7.5-8$ & 5 & $22-23$ & 5 & $4.5-4.75$ & 5 & $40-45$ \\
\hline 6 & 8-8.5 & 6 & $23-24$ & 6 & $4.75-5$ & 6 & $45-50$ \\
\hline \multirow{4}{*}{\multicolumn{2}{|c|}{ ACCEPT > 6.0}} & 7 & $24-25$ & 7 & $5-5.25$ & 7 & $50-55$ \\
\hline & & 8 & $25-26$ & 8 & $5.25-5.5$ & 8 & $55-60$ \\
\hline & & 9 & $26-27$ & \multirow{2}{*}{\multicolumn{2}{|c|}{ ACСЕРТ <4 }} & 9 & $60-65$ \\
\hline & & \multicolumn{2}{|c|}{ ACCEPT > 20} & & & \multicolumn{2}{|c|}{ ACCEPT $<55$} \\
\hline
\end{tabular}

\section{RESULTS DISCUSSION AND ANALYSIS}

The model results for solar energy sites were assessed by evaluating the technical, economic and environmental standard. These were converted to spatial layers as represented on figures (11) to (15).

\section{A. Solar Pond Location In Terms Of Technical Criteria}

Direct normal radiation by data collection from NASA analysis by ArcGIS 10.6.1 using spatial analysis tool option solar radiation Points solar radiation method which calculates digital solar maps as figures by input raster surface and points input feature that determines the locations for solar radiation analysis importance the size cell for all raster maps fixed, the output feature class representing the direct normal radiation or quantity of incoming direct normal solar interpolation for each place, the output solar radiation mapping $\left(\mathrm{kW}-\mathrm{hr} / \mathrm{m}^{2} /\right.$ day). The data and time have 30-year data recorded for each month of year and annual calculated by mean, then the data analysis by the best interpolation category by reclassification method So we create solar map for a total geographic area for each parameters as shown in Charts.

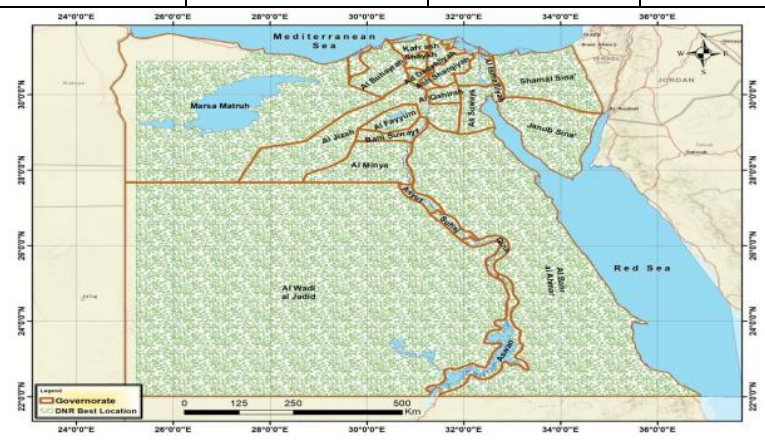

Fig. 11. Solar ponds in terms of DNR criterion

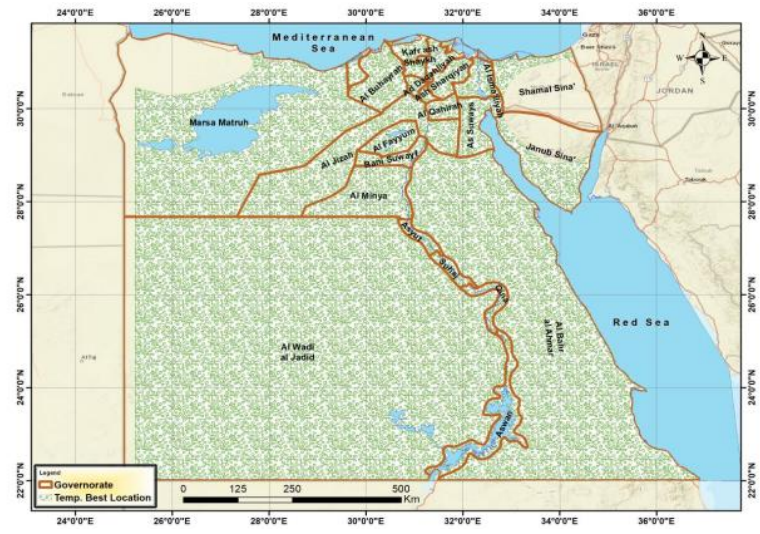

Fig. 12.Solar ponds in terms of temperature criterion

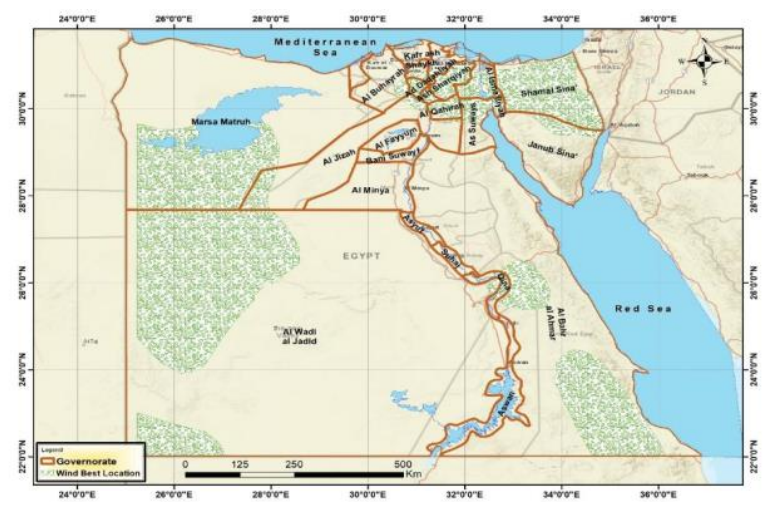

Fig. 13.Solar ponds in terms of wind criterion

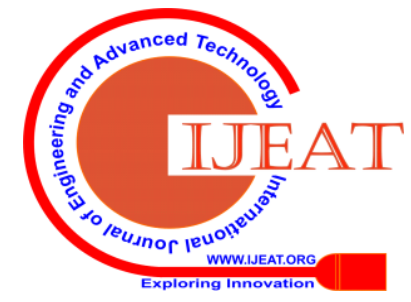




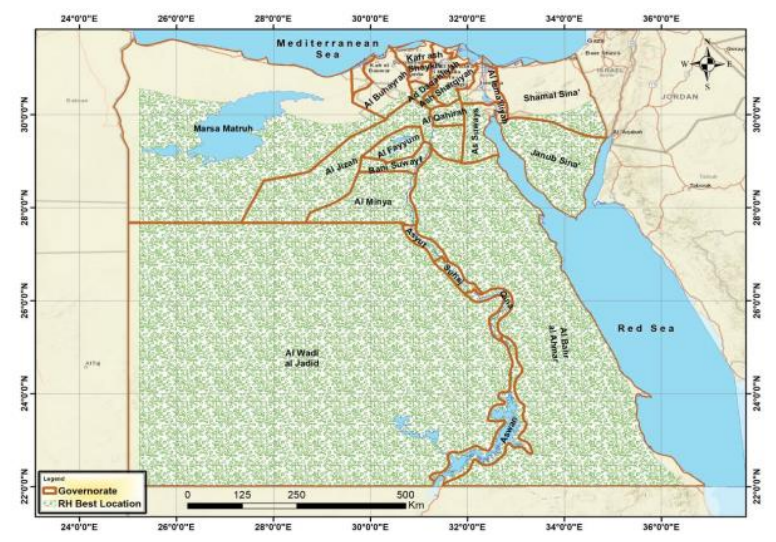

Fig. 14. Solar ponds in terms of relative humidity

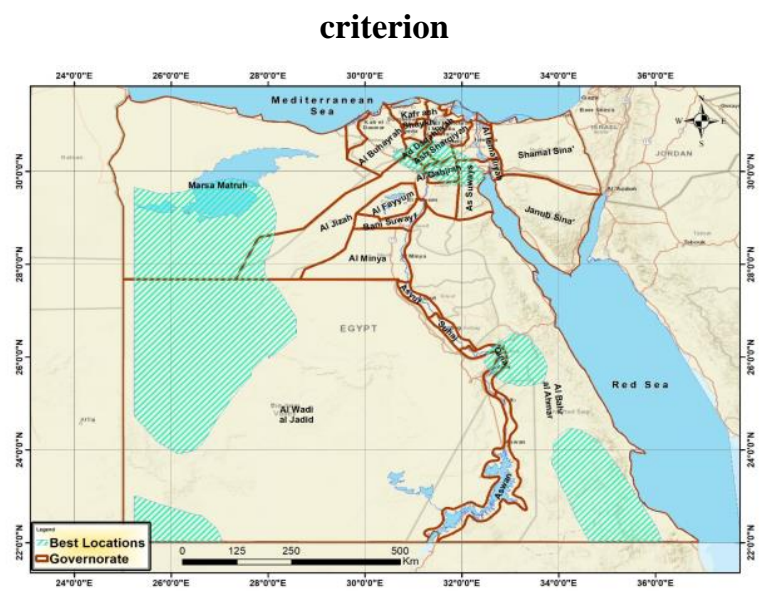

Fig. 15. Suitable locations for solar ponds

\section{APPLYING GIS-AHP MODEL}

Analytic hierarchy process was implemented. The resultant image of each criterion and factor were reclassified by GIS-AHP and the raster map for the suitable location of solar pond in Egypt was obtained. Accordingly, Farafra Oasis, near Dakhla Oasis, Matrouh and Giza Governorate were recommended to be the suitable locations in Egypt.

\section{CONCLUSIONS}

Based on the obtained results, the following conclusions were deduced:

- ArcGIS is a successful tool to produce solar radiation, temperature, wind and relative humidity maps.

- The areas that have potential for solar ponds in Egypt are Farafra Oasis, near the Dakhla Oasis, Matrouh and Giza Governorate.

- Serious work is to be done to reduce the dependency on energy.

- It is necessary to meet the increasing energy demand.

- Solar Pond is a cheap and environment friendly technology.

- Solar pond technique can be applied in power generation, industrial heating processes and desalination.

\section{REFERENCES}

1. CAPMAS, "Central Agency for Public Mobilization and Statistics," 2020. [Online]. Available: https://www.capmas.gov.eg. [Accessed 2020].
2. SIS, "State Information service," 2020. [Online]. Available: http://www.sis.gov.eg. [Accessed 16 January 2020].

3. IRENA, "International Renewable Energy Agency," 2019. [Online]. Available: https://www.irena.org.

4. K. S. a. E.-A. H. Kosmopoulos P., "The Solar Atlas of Egypt," 2018. [Online]. Available: http://www.nrea.gov.eg.

5. NASA, August 2019. [Online]. Available: https://power.larc.nasa.gov.

6. O. e. Dubois, the state of the world's land and water resources for food and agriculture: managing systems at risk., Earthscan, 2011.

7. H. Hoff, "Understanding the nexus: Background paper for the Bonn2011 Conference," 2011.

8. H. e. Qiblawey, "Solar thermal desalination technologies," in Desalination, Elsevier, 2008, pp. 633-644.

9. N. G. a. S. U. S. a. B. J. Mortensen, Wind atlas for Egypt, 3rd Middle East-North Africa Renewable Energy Conference, 2006.

10. H. A.-H. I. A. A. Adel O. Sharif, "New method for predicting the performance of solar pond in any sunny part of the world," Sweden, Linköping University Electronic Press, 2011, pp. pp. 3702-3709.

\section{AUTHORS PROFILE}

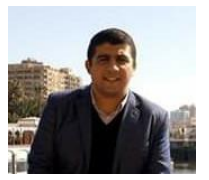

Mohamed Nower Associate Researcher of Irrigation and Hydraulics department of civil Engineering in National water research center (NWRC) in Cairo Egypt. Interested in Energy, management and water sector. Have a special interest in concrete structures. Graduated from Shorouk High Institute, Faculty of Engineering in 2010 grade Excellent with Honor's Degree, 91.07\%, rank $=1 / 480$. Teaching Assistant, Department of Civil Engineering, Shorouk High Institute, Cairo, Egypt. Certificate in project management professional from Canadian academy for science \& technology and Brooklyn academy. "Development of Mix Design Guidelines for Concrete Produced Using Portland cement Types Manufactured According to New Egyptian Standard Specifications," M.Sc. thesis, Faculty of Engineering, Ain Shams University in 2016.

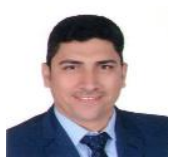

Mohamed Embaby Head of the central GIS unit and researcher at the National Water Research Center, as well as a part-time lecturer in Heliopolis University (HU) and British University in Egypt (BUE). He has 15 years of experience in the field of water resources management and water quality using remote sensing and GIS applications. Dr. Embaby works as a GIS and remote sensing consultant for a number of foreign funded research projects, in addition to local programs in the field of water quality monitoring modelling and assessment, GIS, remote sensing and e-learning. He has a wide experience in developing specialized training programs in the field of Geomatics, Hydro-informatics and land surveying.

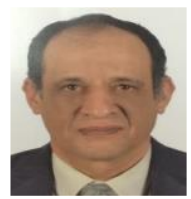

Ashraf Elashaal Professor Emeritus of Dam and Geotechnical Engineering department in National wate research center in Cairo Egypt. Interested in Energy and water sector. Have a special interest in concrete structures. Published 45 papers and articles in differen national and international journal and conferences. Graduated from Cairo University, Faculty of Engineering in 1979 specialized in foundations resting on Problematic soils and earth reinforcement systems. Through his professional career, Involved in various consulting jobs. His professional experience covers areas such as dam design, dam safety, and dam inspection and rehabilitation in U.S.A, Saudi Arabia, South Soudan, Ethiopia and Egypt, slope stability, piling systems, soil investigations, problematic soils, Irrigation and drainage structures, earth structures, canal lining, seepage control, and erosion protection and infra-structures. Gained a wide experience in utilizing field monitoring and physical and numerical modeling as tools of geotechnical and structural analysis. Special experience in designing special foundation systems like floating- foundation, foundation on expansive, dispersive and collapse soils also, he gained a considerable experience in dealing with foundations for high-rise buildings. Teaching subject of dam engineering in the three-month course titled "Integrated Management of River Basins", in addition to tailormade courses in designing dam and hydraulic structures at the regional training center ministry of water resources and irrigation, Egypt. chairman of the Egyptian National Committee on Large Dams and Barrages. Egypt.

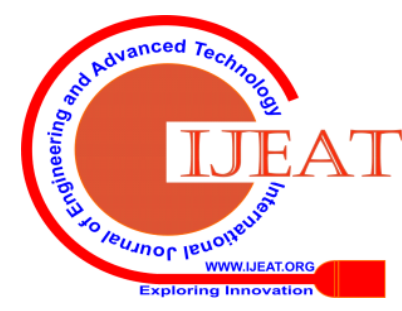


Sonia El-Serafy Professor of Coastal Engineering and Head of the Hydraulics and Engineering Department of Ain Shams University in Cairo Egypt. Interested in shoreline morphology and sediment transport. Have a special interest in concrete structures resistant to chlorides. Published 48 research papers worldwide in the field of Coastal Engineering. Graduated from Ain Shams University, Faculty of Engineering in 1985. Teaching in the same university since then as a teaching assistant, lecturer, assistant professor and professor. Working, as part time in the Arab Academy for Maritime and Transport. Offering consultancy services to private and governmental sectors. Contributing in training of Engineers of the Ministry of Water Resources and Public Works. Offering quality assurance to their publications and reports. Owner to a Scientific Engineering Consultant Office for paraphrasing, editing and translating Engineering books, papers and thesis.

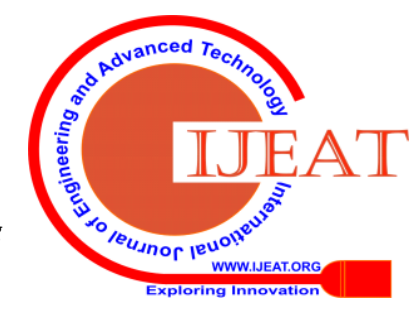

